\title{
Africanization of Christianity: Henry Venn's indigenization of Christianity
}

\author{
Ekpenyong Obo Ekpenyong*1 ${ }^{*}$ Ibiang Obono Okoi ${ }^{2}$ \\ ${ }^{1}$ Department of Religious and Cultural Studies, University of Calabar, Calabar, Nigeria \\ ${ }^{2}$ Department of History and International Studies, University of Calabar, Calabar, Nigeria \\ *e-mail: ekpenyongobo.e@gmail.com
}

\begin{abstract}
Christianity and paganism are reciprocal; Christianity is necessary for revelation to be fulfilled, but the actual quality of this fulfillment depends upon the quality of the religious man transformed by revelation. Christianity, as a result of this, needs a natural religion, the same way it needs all human realities as the sole mission is to save what has first been created. The link between Gospel and culture is that Gospel whenever its introduced and established in a new culture, is "transposed" in a particular way a sweet melody into a new key. Moreover, the Gospel, when transposed from its biblical world to other cultural worlds, undergoes change itself as well as causing these other worlds to change. Crowther created an astonishing impact and contribution after his consecration in 1864; as he strived to indigenize or Africanize Christianity to make it possible for the Christian faith to be accepted by Africans without having to give up or disown their cultural values. This work seeks to find what part Henry Venn, the dynamic and accomplished secretary of the Church Missionary Society, played to see how Christian faith can go well together or combine with African beliefs and practices to produce Christianity which may become a religion for Africans. This work has shown that Henry Venn's ideas on native Church organization include: the native Church needs the ablest native pastors for its fuller development and that it should be under a native bishop and that a native Church is organized as a national institution. This work adopted a qualitative method that used historical and content analysis. This work concluded that for the Africanization of Christianity to be actualized, African Church must have its liturgy or incorporate what was good of the native religions to develop an authentically African Christianity.
\end{abstract}

\section{Keywords:}

Africanization; Christianity; philosophy of education; Henry Venn's Indigenization.

\section{INTRODUCTION}

In particular cultures, the history of Christianity has always been a two-way process of transformation. Jean Danielous has suitably shown or made known the situation in which Christianity and non-Christian traditions provide the same help or advantages to each other in his article title: Christianity and Non-Christian Religions (Nedelea, 2015). He posits that the relationship between Christianity and paganism is reciprocal. Christianity is necessary for revelation to be fulfilled, but the actual quality of this fulfillment depends upon the quality of the religious man transformed by revelation (Nedelea, 2015). As a result of this, Christianity needs a natural religion, the same way it needs all human realities as the sole mission is to save what has first been created. Making the similar perceptive connection between Gospel and culture, proposing that Gospel whenever is introduced and established in a new culture, it is "transposed" in a particular way a sweet melody into a new key. He avers that the Gospel, when transposed from its biblical world to other cultural worlds, undergoes change itself as well as causes these other worlds to change. The Gospel is a very powerful thing. It not only changes human institutions and creates new values, but also changes the hearts of people. But it is not so powerful; he adds that it becomes change-proof. A change-proof Gospel would be a very awkward thing. It could only fit into one situation. If it were rectangular in shape, it could not be fitted into a circle. If it came in white, it could never be black or brown (Stott, 2016). The powerful language that produces pictures in the minds of people reading or listening helps express the creative and dynamic interaction between Gospel and culture in missionary situations.

Lead to the activity of missionary strives of both Protestants and Catholics, Christianity was brought in along the coast and in the Africa interior where no explorers or traders were brave enough to venture Christianity was freely or quickly and without difficulty accepted by the community people either as a means of getting literary skills that were essential for communicating with the outside world or as a way of increasing or furthering improve the good quality, value or status of a community. Henry Venn, the dynamic and accomplished secretary of the Church Missionary Society, averred that "the strategy for mission should be to create as soon as possible an indigenous Church that was self-propagating, self-supporting, and self-governing. He envisioned a situation in which the mission would give way to an indigenous ministry, which would be suited to the local idiosyncrasies" (Wineburg \& Pool 2019, p. 113). To a great extent, Samuel Ajayi Crowther was appointed the first African Bishop of the Anglican Church in West Africa employing Henry-Venn's foresight. Crowther created a very astonishing impact and contribution after his consecration in 1864 to the Niger Delta evangelization. He strived to indigenize or Africanize Christianity to make it possible for the Christian faith to be accepted by Africans not having to give up or disown their cultural values (Barnes, 2018). However, unfortunately, his effort was thwarted and made less effective by the missionaries who firmly demanded to break apart or end the agreement and good relations between African culture and Christianity. 


\section{Conceptual Clarification}

In a quest for clarification of the concept of "Africanization", different terms like indigenization, adaptation, Africanization, and enculturation have been used (Brizuela-Garcia, 2006; offiong, 2016). "Adaptation" speaks about or looks at areas of obvious similarities and contact between African traditional religion and Christianity. According to the advocates of this theory or view, instant adaptation is the thing that has happened when basic principles of Christianity are intended as meaning something that is familiar already (Ruse, 2004). For example, when missionaries traveled to different African villages, they adapted the term for God that was used by the traditional religion. Hence, in Ugep, God is Obase, in Umon, Surrem, in Efik, Abasi, in Igbo, Chineke, in Yoruba, Oluwa and in Hausa,Alla or Ubangiji. This was done to show that Christians worship the same God as the African traditionalists and that the differences are in understanding who this God is.

"Indigenization" on the other hand means the exact thing as enculturation, but indigenization is meant to stress the incarnational aspect (Gray \& Coates, 2016). The idea or principle that is connected with Christology shows that to redeem mankind, Jesus became human in the same vein; for Christianity to reach the soul of the African, it must be African. In other words, for Christianity to acquire the forms, characteristics, and possession of African spirituality, it must grow or develop within the environment of African (Olufu \& Offiong, 2017). "Enculturation" shows the relationship between Christianity and African Traditional Religion, an encounter between two strong cultures. Since Christianity comes from another culture to Africa, it is demanded that it grow within the African culture to become truly African. This transformation process must take place for Christianity to be made the same as the African Cultural background (Ahlberg, 1994). The spirituality of Africa, which is rooted in and strongly influenced by the traditional religions of Africa, had existed long before the advent of Islam and Christianity. It should also be noted that African religion from the time past is twisted together with experiences, history, and cultures of the African peoples. This was what prepared the reception ground for both Christianity and Islam.

Though Western missionaries dismissed by mistakes African traditional religion as being spiritism, paganism, animism or fetishism, some other missionaries acknowledged early enough the efficacious of the African traditional religion. In this way, Smith (1936) believed that Africans had a concept of God long before the arrival of Christianity. A Belgian missionary, Placid Temples believed it was essential to study and understand African traditional religion in order not to destroy African cultures through Christianizing them. His Banti philosophy that was published in 1945, paved the way for the study of African religion sympathetically (Ezugwu, 2014). However, these scholars were an exception in a period or rhetorical misrepresentation of African beliefs. African religion was seen by most of the missionaries within their Western understanding and thereby concluded that it was anti-Christian, heathen, and repulsive (Ndubisi, 2013).

Though African theologies have struggled with the problem of Africanization, the main question here is how Christian faith can go well together or combine with African beliefs and practices to produce Christianity which may become a religion for Africans. In this vein,Justin Ukripo sees syncretism among African Christians as a sign that Christianity has neither taken African culture seriously nor has Christianity been deeply integrated with the indigenous culture. He cited liturgy as an example of this problem (Nthamburi, 1989). Ukripo finally posits that "the liturgy in many mission-founded churches seems to be insensitive to the African, for whom worship is not merely an act of praying and singing. It involves dancing, drumming, clapping hands, and making various bodily gestures (Nthamburi, 1989). He also avers when quotes a Nigerian novelist, OnuoraNzeku, who portrays the syncretistic nature of Igboland Christianity thus:

That is why even though Christianity claims many millions of converts among our people, real converts can be counted on your

fingers and toes alone. Isn't it a shame that Christianity can only boast of millions of hybrids after a hundred years of missionary

activities here? That is converts who are neither Christian nor traditional worshippers but religious bats that belong to no particular faith, only claiming to be one or the other when it suits their purpose (Ukpong, 1984, p. 9).

The missionary societies taught in their schools that Christianity was superior to anything Africans may have developed. Most missionaries were convinced that Africans had no religion, culture, history, literature, art, and music. All these things that distinguish human beings from the other primates were denied of Africa. Although they were supposed to have no concept of God in their own religious heritage, the Bible was translated into African languages, and names for God were found in these languages. Their curriculum was full of prejudice and racial arrogance against Africans.

\section{HENRY VENN's INDIGENIZATION OF CHRISTIANITY}

Henry Venn, grandson of one of the original 'Claphan Sect' and for more than thirty years from 1814 General Secretary of the Church Missionary Society (CMS). He was one of the first to enunciate a policy easier for Protestants than Catholics to envisage: an African Church based on a 'three-self' principle - self-supporting, self-governing and selfpropagating (Tomkins, 2012). Henry Venn became a member of the parent committee of the Church Missionary Society in 1835 and was soon recognized as its leading figure. He became Honorary Secretary of the Society in 1841 and was to remain so for 31 years (1841-72) (Reimer, 2000). Besides serving on two Royal Commissions towards the end of his life, he held no other public office, and his ideas can hardly be discussed without reference to the Society to which he devoted his life and whose needs were always his first consideration. Like the CMS, he grew out of two different movements: the evangelical and the humanitarian (Reimer, 2000). The grandfather of Henry Venn was a junior contemporary of John Wesley and was one of the leaders of the Evangelical Revival within the Anglican Church. One of the founders of the CMS was Venn's father and was rector of Claphan, high priest of the Claphan Sect during the first seventeen years of Henry Venn. 
The abolitionists were embarking on an important change of tactics at the time when Henry Venn became Secretary of the CMS. Until now, they had sought to achieve abolition mainly by a system of laws and treaties with other European and American countries with little reference to Africa itself. By 1841, they were advocating taking the campaign inside Africa and seeking to regenerate the continent by the Bible and the Plough, it was argued that was the only effective means that would produce the intended result to end the trans-Atlantic Slave trade and to make amends to 'down-trodden' Africa for the many wrongs, and evil Europe had meted on her (Davidson, 2019). Henry Venn brought to bear on the preconceived ideas of his age a fresh and vigorous mind, which however reacted to the events and personalities of West Africa and India, Ceylon, and other missionary fields of the CMS, whose affairs he followed closely for so long.

Henry Venn ideas on native Church organization can briefly be summarized as follows: In effect, he claims, the missionary society is a non-profit with limited money but vast fields to cover. Its goal must be to establish "selfgoverning, self-sustaining, self-propagating churches." The Society dispatches and maintains the missionary on the field (Davidson, 2019). His initial converts should be grouped into small groups led by leaders, and they should begin contributing to a Native Church Fund distinct from the missionary society's revenues as soon as feasible. Soon, the bands should join forces and create a congregation under the leadership of a native catechist, whom they should strive to keep. The catechist or another competent native should be ordained pastor soon, allowing the missionary to proceed to new territory. The missionary is to 'use his influence ab extra from now on, prompting and guiding the native pastors in leading their congregations, and making provision for the supply of Catechists, pastors or evangelists' native Church. The missionary that was with the foreign funds is to bring up a native pastorate, but himself must not be the pastor. The pastor must be of the people and maintained by them. That is to say, Venn rejected the Sierra Leone practice where European missionaries acted as pastors and everything was done to conform to the English pattern. Similarly, he rejected the other extreme that he must accept their social standards because the pastor must not be cut off from his flock. 'The native teacher he said, 'should not be too highly praised above his countrymen in his habits and mode of living ... [but] he must always be a little ahead of the civilization of the people around him and by his example and influence lead that civilization forward' (Douglass, 2014, p. 20).

The breath of life in a native Church, according to Henry Venn, depended on 'self-government, self-support, selfextension (Douglass, 2014). That was the lesson Venn learned from his study of the history of earlier Roman Catholic Missions, that the missionary who did not prepare for the day when he would no longer be in the mission by raising up an indigenous clergy and episcopacy was building on sand:

It is expedient that the arrangements which may be made in the missions should have from the first have reference to the ultimate settlement of the native Church upon the ecclesiastical basis of an indigenous episcopate, independent of foreign and or superintendence (Engelke 2007, p. 4).

The way in which Venn developed these ideas into something like a code of missions was his greatest claim to the commanding position he came to occupy in the history of the expansion of the Church. The best-educated pastors were required in any case to organize the different congregations into a native Church as a national institution.

The native Church needs the ablest native pastors for its fuller development. The right position of a native minister and his true independence must now be sought in the independence of the native Church and in its more capable organization under a native bishop. Let a native Church be organized as a national institution .... As a native Church assumes a national character, it will ultimately supersede the denominational distinctions which are now introduced by foreign missionary societies .... Every national Church is at liberty to change its ceremonies and adapt itself to the national taste (Ajayi 1983, p. 176).

However, the work must be of native pastorate. The urge for European missionaries to take over the function of pastor must be strongly resisted, because such a strategy, even if the resources were available, would inevitably result in a feeble and reliant native Christian society. In 1860, the secretaries wrote to the Acting General Superintendent of the Methodist in the Gold Coast and Yoruba thus:

It is of the highest importance to the welfare of the work that wherever societies are formed, they should be trained to support the ministry they enjoy .... A missionary society may confer inestimable blessings in commencing a work in any country; but when a flock is gathered, the Divine Rule requires it should supply the wants of its own shepherds, and not leave them to be provided for by strangers (Ajayi 1983, p. 177).

Raising an indigenous Clergy is a task that must be carried out because nothing that has been achieved is stable without a numerous and indigenous Clergy. I am sure that the training of indigenous Clergy thoroughly for selfgovernment in church affairs will aid in actualizing Africanization of Christianity.

\section{AFRICANIZATION OF CHRISTIANITY}

The modern Christian missionary enterprise, originating in modern 'Christian' Europe, was directed at 'pagan' Africa and other areas where European influence had not yet penetrated. To most missionaries from Europe and North America, evangelization meant disorienting their mission objects from "pagan, heathen, savage, primitive and barbaric" traditions. The practical objective was to form the prospective converts into replicas of the missionary (Jenkins 2011). These pitiable features of our early culture and custom were depicted by Adrain Hastings when he showed how pervasively much of African customs is connected with the fear of sorcery or of cruelty, "to which almost all deaths and other misfortunes were widely ascribed to an endless struggle to protect oneself against" (Uzor, 2004, p. 182). This is cultural clash situation that occurred in Africa. By cultural clash here is not meant that the principles of Christianity as a religion are opposed to the authentic and honest values of African culture. Here, cultural clash must be understood as the conflict between the Western cultural values in which Christianity has been conveyed to Africa and the African culture's authentic values and honest institutions. The process of evangelization and Christianization in Africa had 
brought African and European cultures into contact. Both cultures had experienced reciprocal shocks. The African culture has, however, suffered greater disadvantages from this shock. The waves of missionary activities and Westernization have cast a suppressing and suffocating shadow over most Africans' cultural values (Chitakure, 2017).

The missionary seemed to have formed an idea of their mission to Africa as that of imparting not only the Christian religion but also the Western culture and civilization. They were completely sure of the enormous superiority of the Western culture, which Africa was seen as a cultural "tabula rasa" that must wholly take in if it is to be rescued from the claw of superstition, savagery, barbarism and paganism. This was the early missionaries' mentality in Africa that did not penetrate the mind and cultures of the Africans. This was why most of the converts find it almost impossible to tolerate the foreignness of Christianity.

In 1851, Henry Venn recommended principles whereby an indigenous church would be established. The significant factor was to train African Church leaders and entrust the Churches and evangelize the people to them. Under the guidance of Henry Venn, the Secretary of the Church Missionary Society, indigenous church principles were introduced from the beginning of the ministry (Falk, 2014). "Africans must convert Africa" was another missionary theory. They became aware of this in the early days, on account of the harshness of the climate that caused them to lose an extremely high number of mission personnel. The early converts spontaneously fulfilled this theory as Falk asserted that "The evangelization of Africa has mostly been through the testimony and ministry of African Christians" (p. 430). Missionaries were eager as a rule to learn African languages; most of them also studied tribal customs and history. One of the outstanding was the translation and distribution of the Scriptures by the Protestant missionaries, since Bible reading was for them the most important means of evangelization. For this, Falk affirmed that "for many tribes, the printing of the Bible in their language was synonymous with Christianity having become indigenous" (p. 432). The gross cultural disabilities of the early period have now been overcome and our cultural stage is sufficiently mature and ready for a systematic and institutional indigenization of Christianity.

\section{CONCLUSION}

Venn was urging Crowther to translate the Bible into Yoruba and start to preach in Yoruba even while still at Freetown. Reducing the various African vernaculars into writing and developing native literature was to be a first step in the reforming movement toward Africanization of Christianity. According to Mugambi (2009), "the Africanization of Christianity has been documented in various works. It has occurred in the context of both orthodox and unorthodox initiatives. Many find it impossible to tolerate the foreignness of a denomination established in another country to meet the needs of people in another historical situation. They break away and establish their own denominations in which they can interpret the Gospel without foreign paternalism" (p. 9). Both the orthodox and unorthodox initiatives in the Africanization of Christianity in post-colonial Africa have continued with varying degrees of success from denomination to denomination and from Country to Country. However, the initiatives are there. This African Church was also to have its liturgy or incorporate what was good of the native religions to develop an authentically African Christianity.

\section{REFERENCES}

Ahlberg, B. M. (1994). Is there a distinct African sexuality? A critical response to Caldwell. Africa, 64(2), $220-242$.

Ajayi, J. F. (1983). Christian Missions in Nigeria 1841-1891: The Making of a New Elite. Harlow, England: Longman.

Barnes, A. (2018). Samuel Ajayi Crowther: African and Yoruba Missionary Bishop. In Oxford Research Encyclopedia of African History.

Brizuela-Garcia, E. (2006). The history of Africanization and the Africanization of history. History in Africa, 33, 85-100.

Chitakure, J. (2017). African traditional religion encounters Christianity: The resilience of a demonized religion. Wipf and Stock Publishers.

Davidson, A. K. (2019). Culture and Ecclesiology: The Church Missionary Society and New Zealand. In The Church Mission Society and World Christianity, 1799-1999 (pp. 198-227). Routledge.

Douglass, F. (2014). My bondage and my freedom. Yale University Press.

Engelke, M. (2007). A problem of presence. University of California Press.

Engelke, M. (2010). Number and the imagination of global Christianity; or mediation and immediacy in the work of Alain Badiou. South Atlantic Quarterly, 109(4), 811-829.

Ezugwu, U. J. (2014). Ethnocentric bias in African philosophy vis-à-vis Asouzu'sIbuanyidanda ontology. FilosofiaTheoretica: Journal of African Philosophy, Culture and Religions, 3(1), 41-49.

Falk, P. (2014). The Growth of the Church in Africa. Bukuru, Plateau state, Nigeria: Africa Christian Textbooks (ACTS).

Gray, M., \& Coates, J. (2016). From 'indigenization'to cultural relevance. In Indigenous social work around the world (pp. 41-58). Routledge.

Jenkins, P. (2011). The next Christendom: The coming of global Christianity. OUP USA.

Mugambi, J. N. K. (2009). Christianity and African Culture. Nairobi, Kenya: Action Publishers.

Ndubisi, F. O. (2013). The philosophical paradigm of African identity and development. Open Journal of Philosophy, 3(01), 222.

Nedelea, J. (2015). Christianity and non-Christian religions in Karl Rahner's vision. Journal for the Study of Religions and Ideologies, 14(42), 54-77.

Nthamburi, Z. (1989). Toward indigenization of Christianity in Africa: A missiological task. International Bulletin of Missionary Research, 13(3), $112-118$.

Offiong, E. E. (2016). Environmental degradation and conservation in the Cross River area: A historical appraisal of colonial and post-colonial interventions. People: International Journal of Social Sciences, 2(1), 607-621.

Olufu, G. O., \& Offiong, E. E. (2017). Bekwara and Tiv relations in the Benue-Cross River valley to 1960. Journal Mandyeng Journal of Central Nigeria Studies, 1(1), 76-86.

Reimer, B. (2000). The Spirituality of Henry Venn. Churchman, 114(4), 300-315.

Ruse, M. (2004). Can a Darwinian be a Christian?: the relationship between science and religion. Cambridge University Press.

Smith, E. W. (1936). African Beliefs and Christian Faith. London: the United Society for Christian Literature.

Stott, J. (2006). Basic Christian leadership: Biblical models of Church, gospel and ministry. InterVarsity Press.

Tomkins, S. (2012). The Clapham Sect: How Wilberforce's Circle Transformed Britain. Lion Books.

Ukpong, J. S. (1984). African theologies now: a profile. Spearhead.

Uzor, P. C. (2004). The traditional African concept of God and the Christian concept of God: Chukwu bundu-God is life (The Igbo perspective). Peter Lang.

Wineburg, R., \& Poole, J. (Eds.). (2019). Religion, Welfare and Social Service Provision: Common Ground. MDPI. 